\title{
The role of intravenous iron in the treatment of anemia in cancer patients
}

\section{H.Tilman Steinmetz}

\begin{abstract}
Anemia is a major cause of morbidity in cancer patients resulting in poor physical performance, prognosis and therapy outcome. Initially, erythropoietin-stimulating agents (ESAs) were supposed to be the treatment of choice but about one third of patients turned out to be nonresponders and meta-analyses provided evidence of an increased risk of mortality if used excessively. This along with the successful use of intravenous iron for anemia in patients with chronic kidney disease prompted seven clinical studies evaluating the efficacy of intravenous iron as an adjunct to ESAs and four additional studies using intravenous iron only for anemia in cancer patients. These studies confirmed a superior response if ESAs are combined with intravenous iron and revealed iron only to be a useful option in patients with mild and absolute iron deficiency (AID). Currently, best treatment decisions for anemia in cancer might be based on measurements of serum ferritin (SF), transferrin saturation (TSAT), soluble transferrin receptor (sTfR), ferritin index (FI = sTfR/log SF), hypochromic reticulocytes (CHR) and C-reactive protein (CRP). However, there is still an urgent need for trials investigating diagnostic approaches to optimize therapy of anemia in cancer patients with iron and/or ESAs.
\end{abstract}

Keywords: anemia of chronic disease, cancer, hemoglobin, iron deficiency

\section{Introduction}

Anemia is a major cause of morbidity in cancer patients [Barrett-Lee et al. 2005; Birgegard et al. 2006]. Low hemoglobin ( $\mathrm{Hb})$ levels in cancer patients were shown to correlate significantly with poor physical performance [Ludwig et al. 2004; Barrett-Lee et al. 2005; Birgegard et al. 2006; Steinmetz et al. 2011], prognosis and therapy outcome [Fein et al. 1995; Dubray et al. 1996; Glaser et al. 2001; Littlewood et al. 2001; Waters et al. 2002]. There are multiple causative factors including absolute iron deficiency (AID) which may result from chronic bleeding due to gastrointestinal or gynecological lesions, blood loss from surgery, nutritional deficiencies, anemia of chronic disease (ACD), myelosuppressive effects of chemotherapy or metastatic infiltration of the bone marrow limiting erythropoiesis [Rizzo et al. 2002; Grotto, 2008]. Even in the absence of overt anemia, iron deficiency is already associated with impaired physical function, weakness and fatigue which all abate upon iron therapy [Verdon et al. 2003; Brownlie et al. 2004].
Anemia as major cause of morbidity in cancer took center stage with the approval of erythropoiesis-stimulating agents (ESAs) in 1997. At that time one did not think of functional iron deficiency (FID) in cancer patients yet and AID was generally considered of minor importance. Consequently, diagnostic procedures were not developed but therapy was initiated if three conditions were met: (1) diagnosis of cancer, (2) chemotherapy and (3) low Hb levels $(<10 \mathrm{~g} / \mathrm{dl})$. Accordingly, the first treatment guideline for cancer-associated anemia in 2002 was primarily a 'how to use ESA' guideline [Rizzo et al. 2002]. Only as the sixth of eight recommendations the guideline stated: 'Baseline and periodic monitoring of iron, total iron-binding capacity, transferrin saturation, or ferritin levels and instituting iron repletion when indicated may be valuable in limiting the need for epoetin, maximizing symptomatic improvement for patients, and determining the reason for failure to respond adequately to epoetin. There is inadequate evidence to specify the optimal timing, periodicity, or testing regimen
Ther Adv Hematol (2012) 3(3) 177-191 DOI: $10.1177 /$ 2040620712440071

(c) The Author(s), 2012. Reprints and permissions: http://www.sagepub.co.uk/ journalsPermissions.nav

Correspondence to: H. Tilman Steinmetz, MD Outpatient Clinic for Hematology and Oncology, Sachsenring 69, 50677 Cologne, Germany steinmetzdoncokoeln.de 
for such monitoring'. The ESA-dominated view on anemia did not change with recent guideline revisions and diagnostic procedures of anemia have not been specified at all [Bokemeyer et al. 2007; Rizzo et al. 2010a, 2010b] until the guidelines of the National Comprehensive Cancer Network (NCCN) [NCCN, 2012]. As a consequence, laboratory diagnostics are still hardly used prior to ESA therapy in daily practice [Ludwig et al. 2004; Mitchell, 2010; Steinmetz et al. 2011]. Only about $50 \%$ of physicians make use of laboratory measurements and most use ferritin only.

Routine practice of triggering ESA treatment of cancer-related anemia based on chemotherapy and low Hb-values only [Steinmetz et al. 2008] has resulted in overall response rates of about $50-60 \%$ and the need for blood transfusion has remained high, at about $20-30 \%$. Moreover, during recent years, evidence has been increasing that aggressive ESA treatment as well as blood transfusions may increase all-cause mortality [Spahn et al. 2008; Bohlius et al. 2009] although no such evidence is available if ESAs are used according to the label with target $\mathrm{Hb}$ levels between 11-12 g/dl [Glaspy et al. 2010].

The poor response rates to ESA therapy alone and the positive experience with intravenous iron in chronic kidney disease prompted the first study of the combination treatment of ESAs and intravenous iron in cancer patients [Auerbach et al. 2004]. This was followed by six additional studies using iron as an adjunct to ESAs and by four studies using even iron alone in anemic cancer patients. In parallel, the understanding of the pathophysiology of cancer-related anemia has grown substantially [Grotto, 2008] and the detection of hepcidin opened new insights into the regulation of iron metabolism and hematopoiesis [Krause et al. 2000; Park et al. 2001; Goodnough et al. 2010; Thomas et al. 2011]. Consequently, the ACD which has already been known to cause anemia in cancer patients prior to the era of ESAs [Cash and Sears, 1989] came to the fore again [Weiss and Goodnough, 2005] whereas the effect of chemotherapy stood back. With the rediscovery of the concept of ACD the role of iron has changed too. While during the early ESA years iron was used in AID only, the FID described in ACD may explain benefits of iron also in patients with normal or even elevated total body iron. This review focuses on when and how to use iron in cancer-related anemia.

\section{Pathophysiology of anemia in cancer and derived diagnostic tests}

Based on WHO criteria [de Benoist et al. 2008] the definition of anemia is relatively simple: $\mathrm{Hb}$ $<12 \mathrm{~g} / \mathrm{dl}$ in nonpregnant women and $\mathrm{Hb}<13 \mathrm{~g} /$ $\mathrm{dl}$ in male subjects older than 15 years. However, the problem of anemia in cancer is complex and it is not only challenging to identify causes in any given patient, but also to evaluate the relevance of single factors in general. If indicated by a careful anamnesis, initially bone marrow infiltration, hemolytic anemia, renal insufficiency and vitamin deficiency should be ruled out by bone marrow aspiration, measurement of serum levels of lactate dehydrogenase (LDH) and haptoglobin, of creatinine clearance and endogenous erythropoietin, and of vitamin B12 and folic acid, respectively (Figure 1). However, the diagnosis of iron deficiency is not as easy, as one needs to discriminate AID and FID [NCCN, 2012].

AID is a common cause of anemia in cancer patients, most often provoked by bleeding or iatrogenic blood loss, less frequently for dietary reasons. Low values of the erythrocyte indices major histocompatibility complex (MHC), mean corpuscular volume (MCV) and mean corpuscular hemoglobin concentration (MCHC) indicate diminished iron incorporation. Most often serum iron $(\mathrm{Fe})$ is low in AID, but strongly varies with inflammatory reactions; moreover, it might be low in FID too. The most important parameter to assess whole body iron is serum ferritin (SF) which is the intracellular storage protein of iron; $1 \mu \mathrm{g} / 1 \mathrm{SF}$ corresponds to about $8-10 \mathrm{mg}$ of iron stored. AID is defined as SF $<30 \mu \mathrm{g} / 1$ and decreased saturation of serum transferrin (TSAT) $<15 \%$ [NCCN, 2012]. Unfortunately, SF is an acute phase protein. Consequently during an inflammatory reaction, serum levels increase and there is no longer a clear-cut SF threshold indicating AID; however, SF levels $<100 \mathrm{ng} / \mathrm{ml}$ make AID very likely and are therefore predictive of a good response to $\mathrm{Fe}$ iv, without using ESA [Auerbach et al. 2010; Steinmetz et al. 2011]. Alternatively, intracellularly stored iron might be detected through staining of bone marrow smears which is not very practical though. However, the combination of SF, C-reactive protein (CRP), soluble transferrin receptor (sTfR), and low $\mathrm{Hb}$-content of reticulocytes (Ret-Y, CHR) enables the detection of AID [Thomas and Thomas, 2002] even though $S F$ levels might be $>1000 \mu \mathrm{g} / 1$ [Steinmetz et al. 2010]. 


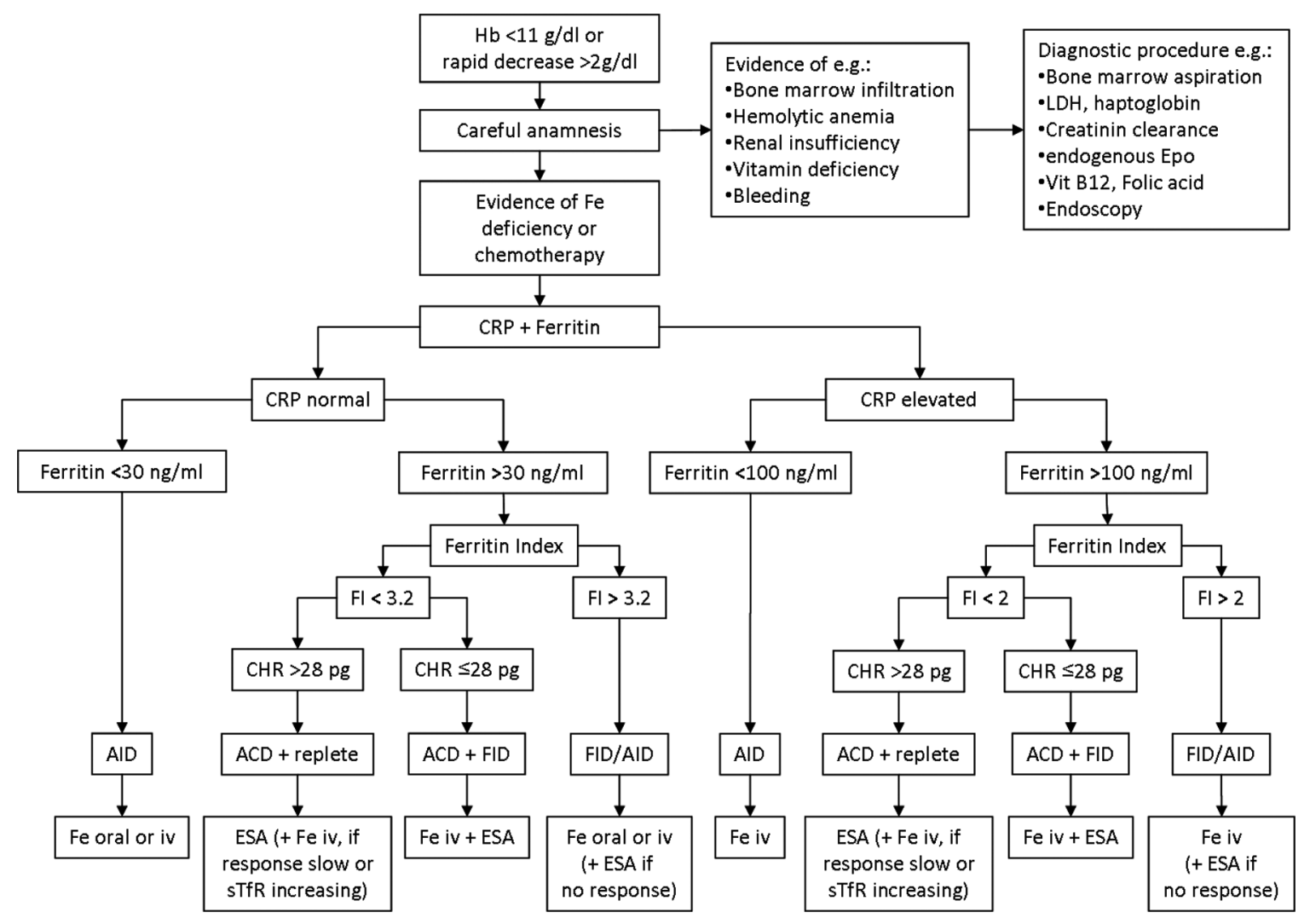

Figure 1. Proposal of a diagnostic and treatment algorithm lincorporating the diagnostic plot of Thomas and Thomas [2002]). ESA: erythropoietin-stimulating agent; FID, functional iron deficiency; CRP, C-reactive protein; ACD, anemia of chronic disease; AID, absolute iron deficiency; CHR, hypochromic reticulocytes.

FID is a major contributor to ACD and accordingly also quite prevalent in cancer-associated anemia [Ludwig et al. 2011]. FID in cancer is most often provoked by tumor cells that interact with the immune system and by this cause a chronic state of inflammation along with the release of pro-inflammatory cytokines, such as interleukin-6 (IL-6) or tumor necrosis factor (TNF). In the clinical setting the extent of inflammation could be assessed through measurement of CRP, which is closely related to the serum IL-6 level. Cytokines foster the release of hepcidin, a peptide hormone and key regulator of iron homeostasis [Weiss and Goodnough, 2005]. Hepcidin blocks the membrane-tunnel protein ferroportin which normally transfers iron from the intracellular stores to transferrin, the transport protein in blood. Therefore, in the case of inflammatory reactions, increasing hepcidin levels lock iron in the cells; dietary iron is not released from the enterocytes in the small intestine, nor is storage iron released from the cells of the reticulo-endothelial system (e.g. macrophages, liver cells). As a consequence of the intracellular iron accumulation, the saturation of the iron transporting protein transferrin decreases. Therefore, despite high intracellular iron levels, a FID develops due to the restricted supply of iron to erythropoiesis (iron restricted erythropoiesis [IRE]). NCCN guidelines define FID if TSAT is $<20 \%$ along with normal or elevated SF levels up to $800 \mu \mathrm{g} / 1$ [NCCN, 2012]. During inflammation SF and hepcidin increase whereas transferrin decreases. As a consequence TSAT might be within the normal range and thus is not a good indicator for intravenous iron [Auerbach et al. 2010; Steinmetz et al. 2011]. Hepcidin might be an alternative, but is unfortunately not yet available as a routine test [Goodnough et al. 2010; Thomas et al. 2011].

As iron is most important for the production of hemoglobin, IRE results in hypochromic anemia which is characterized initially by an increasing number of hypochromic reticulocytes (CHR, Ret-Y), and later by hypochromic erythrocytes (Hypo-Ery) [Brugnara, 2000; Thomas and Thomas, 2002; Goodnough et al. 2010]. In an 
attempt to compensate for this anemia the quantity of erythropoietic precursor cells (erythroblasts and proerythroblasts) and the number of transferrin receptors on the surface of these precursor cells increase. The transferrin receptor is shed into the plasma where the sTfR concentration correlates with the surface amount. Thus, an elevated level of sTfR reflects an increased number of erythropoietic precursor cells and an increasing iron need for erythropoiesis [Cazzola and Beguin, 1992; Pettersson et al. 1994; Suominen et al. 2000; Beguin, 2002; Lee et al. 2002]. The value of sTfR alone for the differential diagnosis of anemia and for the prediction of treatment response is rather low [Steinmetz et al. 2007], but the ratio of sTfR and the logarithm of serum ferritin (sTfR/ $\log \mathrm{SF}$ ), the so-called ferritin index (FI), proved to discriminate FID and ACD [Punnonen et al. 1997]. However, cancer patients often have normal sTfR and FI despite a proven AID [Lee et al. 2002]. This may be explained by direct suppression of erythropoiesis through tumor cells and chemotherapy and a reduced production of endogenous erythropoeitin [Weiss and Goodnough, 2005]. The combination of the FI with the determination of hypochromic reticulocytes enables identification of patients with ACD, repleted iron stores (FI normal), but FID (CHR $\leq 28$ pg) [Thomas and Thomas, 2002].

\section{Studies of iron as an adjunct to ESA for the treatment of anemia associated with chemotherapy}

Approximately $30-50 \%$ of cancer patients with chemotherapy-related anemia do not respond to ESA alone and even in the remaining patients, response is often slow, not until 4-6 weeks after ESA initiation [Glaspy et al. 1997; Littlewood et al. 2001]. As response to ESA was shown to improve with intravenous iron supplementation in chronic kidney disease [Fishbane et al. 1995; Macdougall et al. 1996; Sepandj et al. 1996], Auerbach and colleagues performed the first randomized controlled-pilot trial testing combinations of ESAs and iron in cancer patients with chemotherapyrelated anemia [Auerbach et al. 2004] (Table 1). Intravenous iron was superior to oral iron or ESA alone in increasing $\mathrm{Hb}$ and quality of life (QoL). Subsequently, five studies [Hedenus et al. 2007; Henry et al. 2007; Bastit et al. 2008; Pedrazzoli et al. 2008; Auerbach et al. 2010] confirmed a better response rate of intravenous iron along with ESAs as compared with ESA alone (Table 1). In three studies using Epoetin alpha or beta, adjunct treatment with intravenous iron increased the $\mathrm{Hb}$ response rate $(\Delta+0.8$ to $1.2 \mathrm{~g} / \mathrm{dl})$ from $36-53 \%$ to $68-93 \%$ versus ESAs alone [Auerbach et al. 2004; Hedenus et al. 2007; Henry et al. 2007], i.e. an improvement of $28-40 \%$. In three studies using darbepoetin alpha, the response rate to ESA alone was slightly higher at $62-73 \%$. The addition of intravenous iron improved these rates by about $10-15 \%$ to an overall response rate of $77-86 \%$. Moreover, there was a quicker onset of response in four [Hedenus et al. 2007; Bastit et al. 2008; Pedrazzoli et al. 2008; Auerbach et al. 2010] and an improvement of QoL in two [Auerbach et al. 2004; Bastit et al. 2008] out of six studies. The rate of transfusions in the ESA alone and the combined ESA and oral iron groups varied significantly among the six studies from 3\% to 30\% and in one only study intravenous iron significantly reduced the rate from $26 \%$ to $16 \%$ [Bastit et al. 2008]. An ESA dose saving effect was demonstrated in another study [Hedenus et al. 2007].

There was only one study that despite its large size failed to demonstrate significant clinical benefit of adjunct intravenous iron [Steensma et al. 2011]. A higher $\mathrm{Hb}$ response in the intravenous iron group was not significant, improvement of QoL was comparable and rates of transfusion were the same in all three study arms. Moreover, the study reported a higher rate of serious adverse events (SAEs) in the intravenous iron group as compared with the oral or no iron groups (55\% versus $45 \%$ and $46 \%$, respectively). Aapro and colleagues argued that the study might have failed due to the relatively low total ( $937.5 \mathrm{mg}$ iron) and weekly iron dose $(62.5 \mathrm{mg})$ and the high dropout rate due to which many patients did not receive the planned dose [Aapro et al. 2011]. Indeed, patients who received at least $750 \mathrm{mg}$ of iron had a higher response rate than those who received less than $750 \mathrm{mg}$ intravenous, oral or no iron ( $80 \%$ versus $56 \%, 67 \%$ and $65 \%$, respectively) [Steensma, 2011].

\section{Studies using iron alone for treatment of anemia in cancer patients}

The first study investigating intravenous iron alone in chemotherapy-associated anemia was performed in women with cervical cancer treated with chemoradiotherapy [Kim et al. 2007] (Table 2). The primary objective was to prevent exacerbation of anemia and to reduce the transfusion volume through intravenous iron sucrose. In the setting of this single-center 


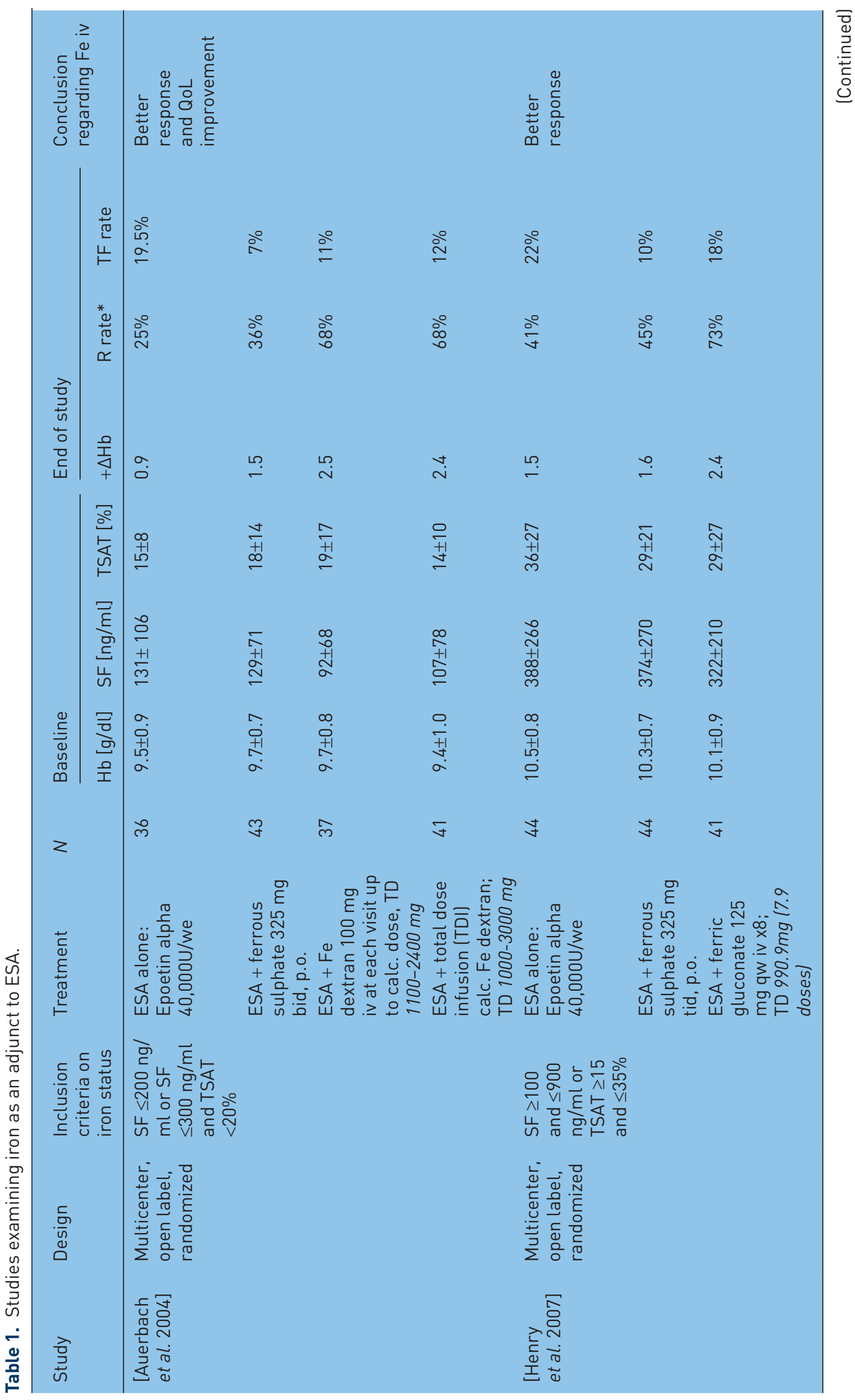




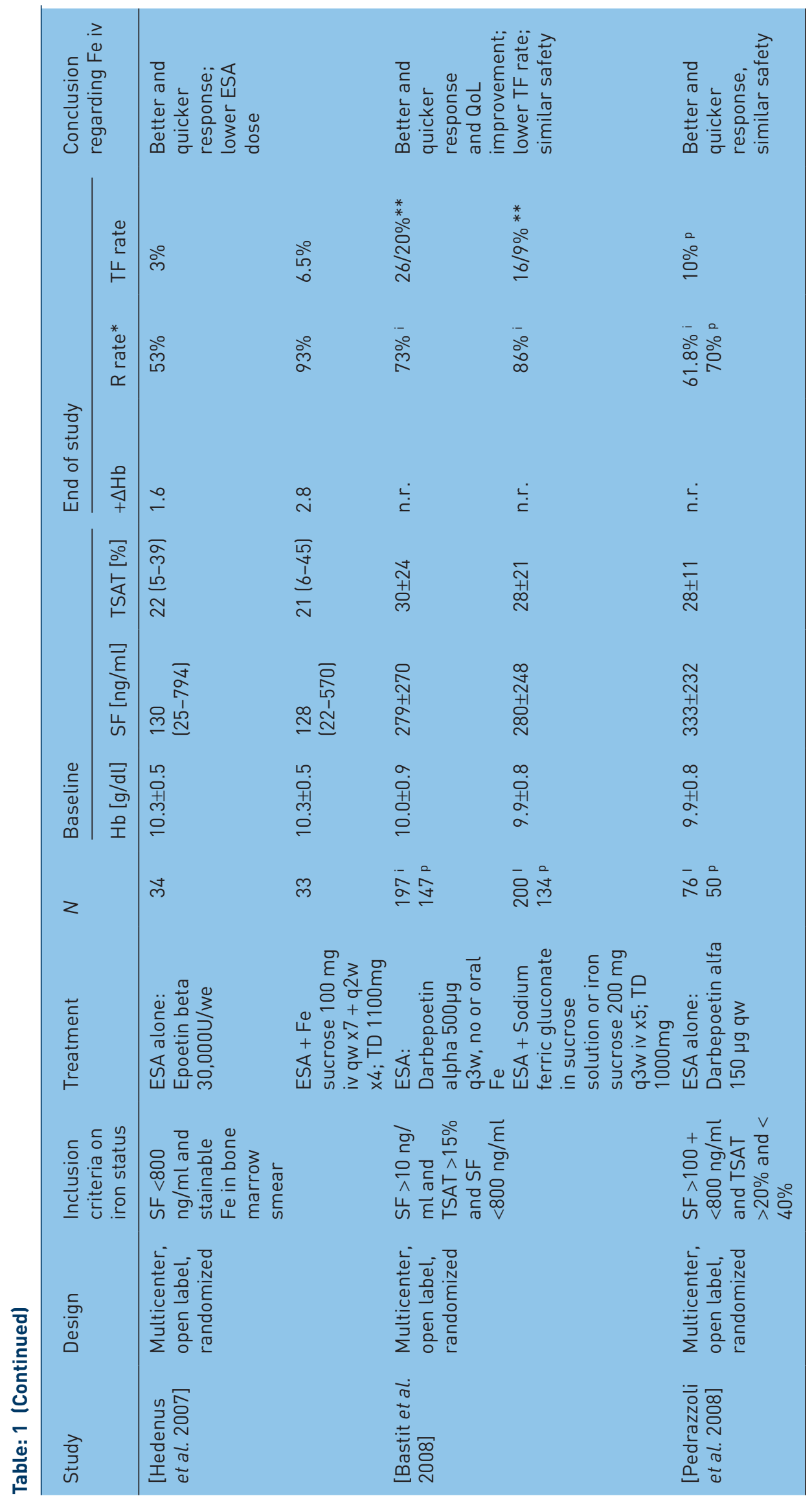




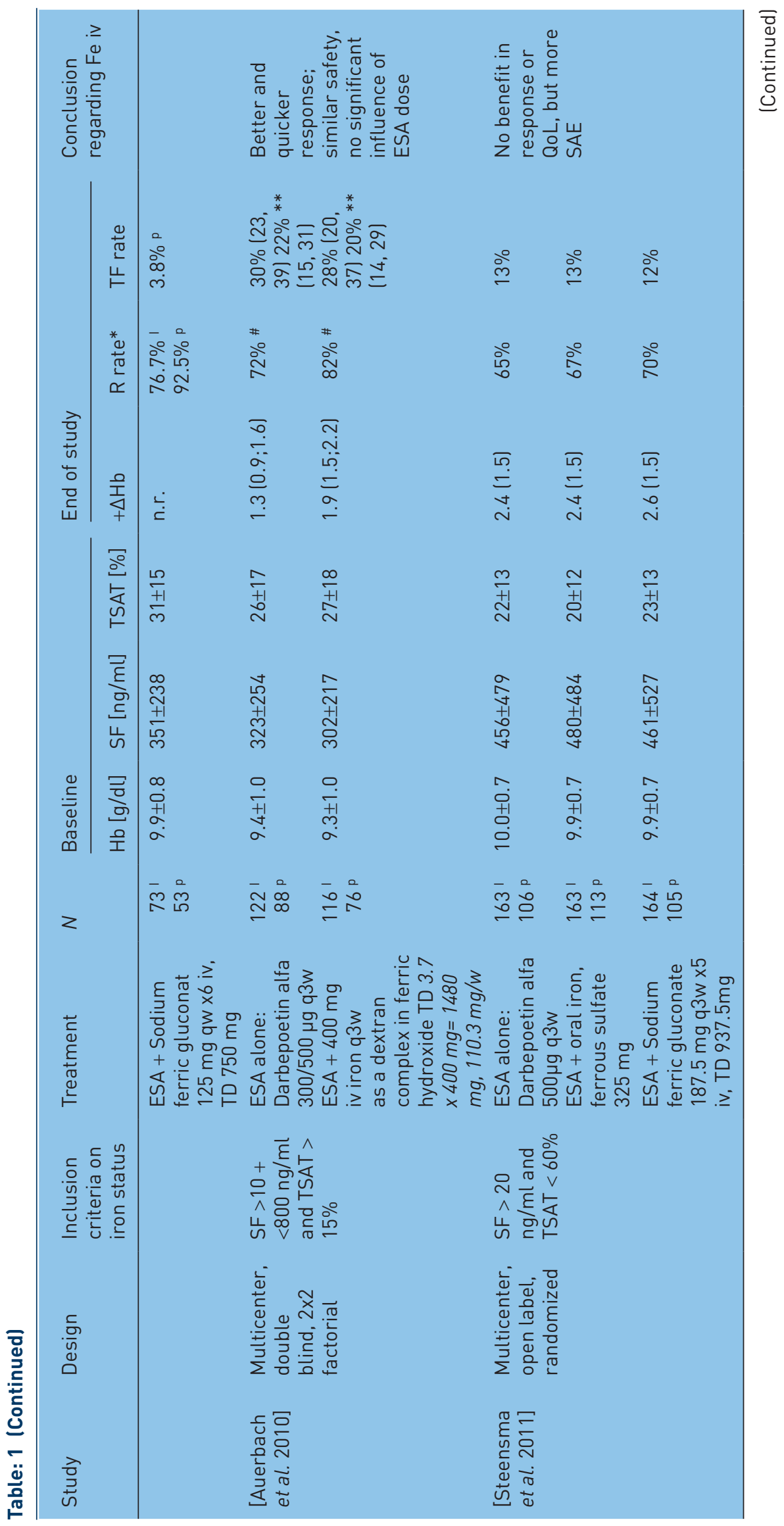




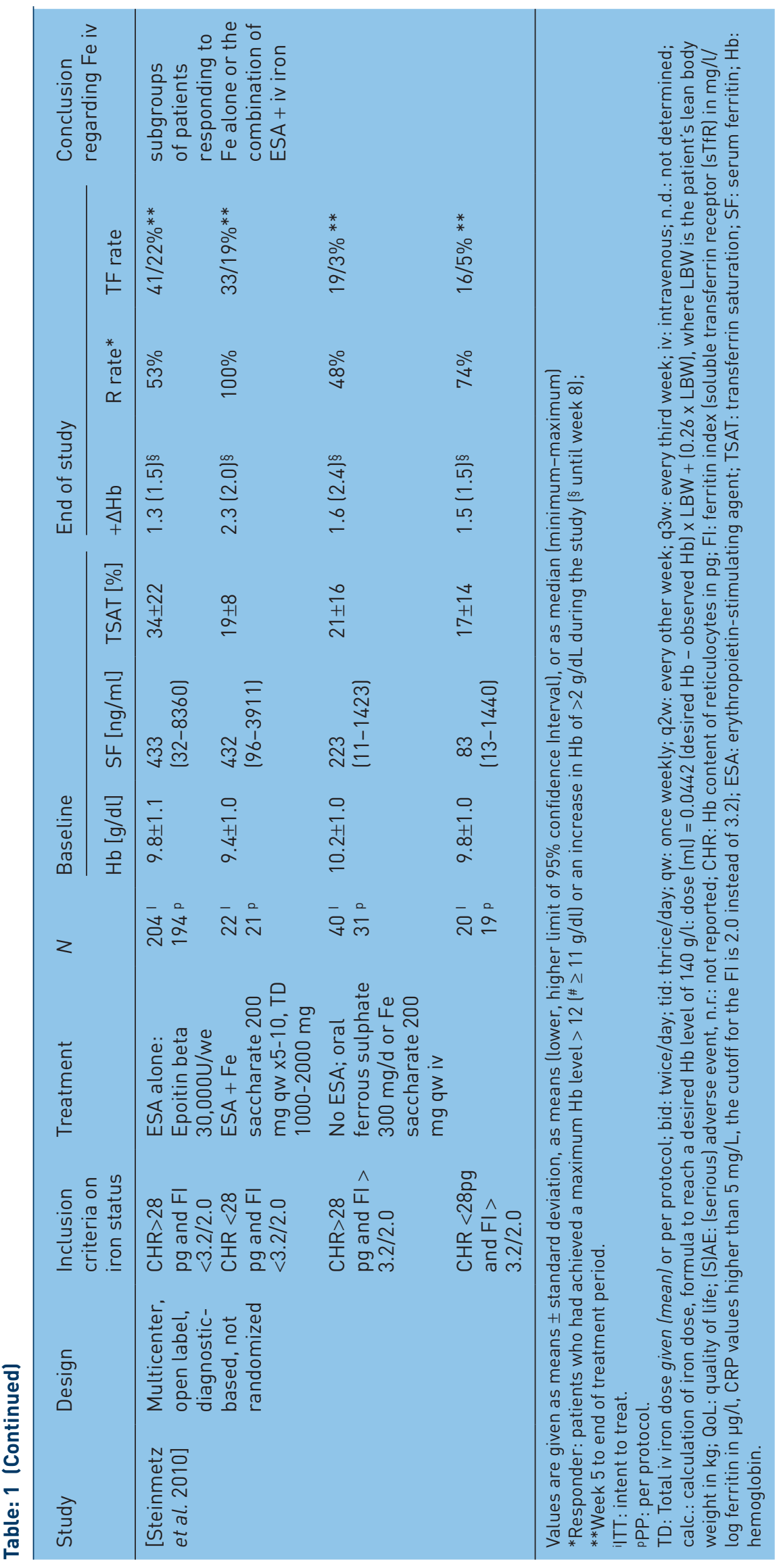


Table 2. Studies examining intravenous iron alone

\begin{tabular}{|c|c|c|c|c|c|c|}
\hline Study & \multicolumn{2}{|c|}{ [Kim et al. 2007] } & \multicolumn{2}{|c|}{$\begin{array}{l}\text { [Dangsuwan and Manchana, } \\
\text { 2010] }\end{array}$} & \multicolumn{2}{|c|}{ [Steinmetz et al. 2011] } \\
\hline Design & \multicolumn{2}{|c|}{$\begin{array}{l}\text { single center, prospective, open } \\
\text { label, randomized }\end{array}$} & \multicolumn{2}{|c|}{$\begin{array}{l}\text { single center, prospective, open } \\
\text { label, randomized }\end{array}$} & \multicolumn{2}{|c|}{$\begin{array}{l}\text { multi-center, prospective, } \\
\text { non-interventional }\end{array}$} \\
\hline Objective & \multicolumn{2}{|c|}{$\begin{array}{l}\text { To prevent exacerbation } \\
\text { of anemia and reduce the } \\
\text { transfusion volume in cervical } \\
\text { cancer patients treated with } \\
\text { chemoradiotherapy }\end{array}$} & \multicolumn{2}{|c|}{$\begin{array}{l}\text { To reduce RBC transfusions } \\
\text { in anemic gynecologic cancer } \\
\text { patients receiving platinum- } \\
\text { based chemotherapy }\end{array}$} & \multicolumn{2}{|c|}{$\begin{array}{l}\text { To evaluate the effectiveness } \\
\text { and tolerability of FCM in routine } \\
\text { treatment of anemia in cancer } \\
\text { patients }\end{array}$} \\
\hline Fe treatment & - & $\begin{array}{l}\text { Iv iron sucrose } \\
200 \mathrm{mg} \text { in } 200 \\
\mathrm{ml} \mathrm{NaCl} \text { if } 10< \\
\mathrm{Hb}<12 \mathrm{~g} / \mathrm{dl}\end{array}$ & $\begin{array}{l}200 \mathrm{mg} \text { of } \\
\text { oral ferrous } \\
\text { tid }\end{array}$ & $\begin{array}{l}\text { Iv iron sucrose } \\
200 \mathrm{mg} \text { in } 200 \\
\mathrm{ml} \mathrm{NaCl} \text { if } \mathrm{Hb} \\
<10 \mathrm{~g} / \mathrm{dl}\end{array}$ & $\begin{array}{l}\text { FCM dose and } \\
\text { frequency at } \\
\text { discretion of the } \\
\text { oncologist }\end{array}$ & $\begin{array}{l}\text { FCM dose and } \\
\text { frequency and } \\
\text { ESA treatment } \\
\text { at discretion of } \\
\text { the oncologist }\end{array}$ \\
\hline $\begin{array}{l}\text { Fe inclusion } \\
\text { criteria }\end{array}$ & \multicolumn{2}{|l|}{ None } & \multicolumn{2}{|l|}{ none } & \multicolumn{2}{|c|}{$\begin{array}{l}\text { Anemia and need of iron at } \\
\text { discretion of the oncologist }\end{array}$} \\
\hline$N$ of patients & 45 & 30 & 22 & 22 & 347 & 73 \\
\hline TD Fe iv [mg] & - & n.r. & n.r. & n.r. & \multicolumn{2}{|l|}{$1000(600,1500)$} \\
\hline $\mathrm{Hb}[\mathrm{g} / \mathrm{dl}]$ & $11.33(2.14)$ & 11.27 (1.94) & $9.0(0.6)$ & $8.9(0.6)$ & $10.1(1.0)$ & $9.6(1.1)$ \\
\hline $\mathrm{SF}[\mathrm{ng} / \mathrm{ml}]$ & n.r. & n.r. & n.r. & n.r. & 334 (500) & 461 (491) \\
\hline TSAT [\%] & n.r. & n.r. & n.r. & n.r. & $15(16)$ & $27(30)$ \\
\hline$+\Delta \mathrm{Hb}[\mathrm{g} / \mathrm{dl}]$ & n.r. & n.r. & $\begin{array}{l}0.4(-2.1 \\
\text { to } 3.0)\end{array}$ & $0.9(-0.9$ to 2.6$)$ & $1.4(0.2,2.3)$ & $1.6(0.7,2.4$ \\
\hline TF rate & $64 \%$ & $40 \%$ & $63.6 \%$ & $22.7 \%$ & $\begin{array}{l}\text { Week } 1-412 \% \\
\text { Week }>57 \%\end{array}$ & $\begin{array}{l}\text { Week } 1-423 \% \\
\text { Week }>511 \%\end{array}$ \\
\hline $\begin{array}{l}\text { Conclusion } \\
\text { regarding Fe iv }\end{array}$ & \multicolumn{2}{|c|}{$\begin{array}{l}\text { Reduced TF rate; similar rate of } \\
A E \text { and } S A E\end{array}$} & \multicolumn{2}{|c|}{$\begin{array}{l}\text { Reduced TF rate; superior } \mathrm{Hb} \\
\text { increase; similar rate of } \mathrm{AE} \text { and } \\
\mathrm{SAE}\end{array}$} & \multicolumn{2}{|c|}{$\begin{array}{l}\text { High efficacy of FCM, even without } \\
\text { ESA; good tolerability and safety }\end{array}$} \\
\hline
\end{tabular}

trial the transfusion rate dropped from $64 \%$ to $40 \%$. Another single-center, prospective, openlabel, randomized study explored whether intravenous iron reduces red blood cell (RBC) transfusions in anemic gynecologic cancer patients receiving platinum-based chemotherapy [Dangsuwan and Manchana, 2010]. Again, this was a small study enrolling 22 patients per arm only, but intravenous iron resulted in a significant $\mathrm{Hb}$ increase of $0.9 \mathrm{~g} / \mathrm{dl}$ and a significant reduction of the transfusion rate from $63.6 \%$ to $22.7 \%$. While in both of these studies [Kim et al. 2007; Dangsuwan and Manchana, 2010] all patients received intravenous iron regardless of patients' actual iron status, in the German TANDEM trial patients were assigned to different treatment regimens based on the results of the diagnostic plot [Thomas and Thomas, 2002]. This diagnostic tool revealed in $207(68 \%)$ out of 303 patients with a baseline ferritin $\geq 20 \mathrm{ng} / \mathrm{ml}$ no iron deficiency and were treated with ESAs alone. A total of 23 patients ( $8 \%$ ) had ACD with FID and received ESA + intravenous iron, while 46 $(15 \%)$ and $27(9 \%)$ patients had mild and distinct AID, respectively, and received either oral or intravenous iron alone. Response rates were comparable in all groups, but the need for transfusions was slightly lower in groups receiving iron only [Steinmetz et al. 2010] (Table 1).

The so far largest cohort of cancer patients treated for anemia with iron alone was in an observational study in Germany enrolling a total of 420 patients [Steinmetz et al. 2011]. Of these $347(82.6 \%)$ received ferric carboxymaltose (FCM) as intravenous iron preparation only, the remaining $73(17.3 \%)$ patients received FCM as an adjunct to ESA. About three out of four patients $(74.3 \%)$ received cytotoxic chemotherapy concomitantly. At baseline, median $\mathrm{Hb}$ was $10.0 \mathrm{~g} / \mathrm{dl}(95 \%$ confidence interval [CI] 9.110.6 ), ferritin was $\leq 100 \mathrm{ng} / \mathrm{ml}$ in $37.5 \%$, and transferrin saturation $<20 \%$ in $75.6 \%$ of patients. Average increase in $\mathrm{Hb}$ levels was $1.4 \mathrm{~g} / \mathrm{dL}$ 
Table 3. Iron preparations for intravenous use.

\begin{tabular}{|c|c|c|c|}
\hline $\begin{array}{l}\text { Formulation (brand, } \\
\text { companyl }\end{array}$ & Iron $[\mathrm{mg} / \mathrm{ml}]$ & $\begin{array}{l}\text { Volume and Fe } \\
\text { content / vial }\end{array}$ & Dosing instructions \\
\hline $\begin{array}{l}\text { Ferric natrium-gluconat- } \\
\text { sucrose complex } \\
\text { (EU: Ferrlecit } ®, \text { Sanofi- } \\
\text { Aventis; US: Ferrlecit@; } \\
\text { Watson Pharma, Inc) }\end{array}$ & 12.5 & $\begin{array}{l}3.2 \mathrm{ml}=40.0 \mathrm{mg} \\
5.0 \mathrm{ml}=62.5 \mathrm{mg}\end{array}$ & $\begin{array}{l}\text { Very slow injection or infusion } \\
\text { with } 62.5 \mathrm{mg} \text { in } 100-250 \mathrm{ml} \text { over } \\
30 \mathrm{~min}\end{array}$ \\
\hline $\begin{array}{l}\text { Ferric hydroxyd- } \\
\text { dextran complex } \\
\text { (EU: Cosmofer }{ }^{\circledR} \text {, } \\
\text { Pharmacosmos, Holbek, } \\
\text { Denmark) }\end{array}$ & 50 & $\begin{array}{l}2.0 \mathrm{ml}=100 \mathrm{mg} \\
5.0 \mathrm{ml}=250 \mathrm{mg} \\
10.0 \mathrm{ml}=500 \mathrm{mg}\end{array}$ & $\begin{array}{l}25 \mathrm{mg} \text { iron as a test-dose in } \\
15 \mathrm{~min} . ; 60 \mathrm{~min} \text { later: Infusion } \\
\text { maximal } 200 \mathrm{mg} \text { iron in } 100 \mathrm{ml} \text { in } \\
\text { at least } 30 \mathrm{~min} . \\
\text { Maximum dose: } 20 \mathrm{mg} / \mathrm{kg} \text { body } \\
\text { weight in } 4-6 \mathrm{~h}\end{array}$ \\
\hline $\begin{array}{l}\text { Ferric hydroxid- } \\
\text { saccharose complex } \\
\text { (EU: FerMed®, Medice } \\
\text { Arzneimittel Pütter, } \\
\text { Iserlohn, Germany) }\end{array}$ & 20 & $5.0 \mathrm{ml}=100 \mathrm{mg}$ & $\begin{array}{l}\text { Not exceeding } 200 \mathrm{mg} \text { iron in } \\
200 \mathrm{ml} \text { in at least } 30 \mathrm{~min} \text {. } \\
\text { Maximum dose: } 200 \mathrm{mg} \text { per day }\end{array}$ \\
\hline $\begin{array}{l}\text { Ferric hydroxid- } \\
\text { saccharose complex (EU: } \\
\text { Venofer } ® \text {, Vifor Pharma, } \\
\text { Bern, Switzerland; US: } \\
\text { Venofer } ® ; \text { American } \\
\text { Regent, Inc) }\end{array}$ & 20 & $\begin{array}{l}2.5 \mathrm{ml}=50 \mathrm{mg} \\
5.0 \mathrm{ml}=100 \mathrm{mg}\end{array}$ & $\begin{array}{l}25 \mathrm{mg} \text { iron as a test dose in } \\
15 \mathrm{~min} \text {. } \\
\text { Not exceeding } 200 \mathrm{mg} \text { iron in } \\
200 \mathrm{ml} \text { in at least } 30 \mathrm{~min} \text {. } \\
\text { Maximum dose: } 200 \mathrm{mg} \text { per day }\end{array}$ \\
\hline $\begin{array}{l}\text { Ferric carboxymaltose } \\
\text { (EU: Ferinject }{ }^{\circledR} \text {, } \\
\text { Vifor Pharma, Bern, } \\
\text { Switzerland) }\end{array}$ & 50 & $\begin{array}{l}2.0 \mathrm{ml}=100 \mathrm{mg} \\
10.0 \mathrm{ml}=500 \mathrm{mg}\end{array}$ & $\begin{array}{l}\text { Test dose not recommended; } \\
\text { not exceeding } 1000 \mathrm{mg} \text { iron in } \\
250 \mathrm{ml} \text { in at least } 15 \mathrm{~min} \text {. } \\
\text { Maximum dose: } 1000 \mathrm{mg} \text { per } \\
\text { day }\end{array}$ \\
\hline $\begin{array}{l}\text { Iron isomaltosid } \\
\text { (EU: Monofer®, } \\
\text { Pharmacosmos, Holbek, } \\
\text { Denmark) }\end{array}$ & 100 & $\begin{array}{l}1.0 \mathrm{ml}=100 \mathrm{mg} \\
2.0 \mathrm{ml}=200 \mathrm{mg} \\
5.0 \mathrm{ml}=500 \mathrm{mg} \\
10.0 \mathrm{ml}=1000 \mathrm{mg}\end{array}$ & $\begin{array}{l}\text { Test dose not recommended; } \\
\text { bolus injection of maximal } \\
200 \mathrm{mg} \text { in } 4 \mathrm{~min} \text {; not exceeding } \\
20 \mathrm{mg} \text { iron per } \mathrm{kg} \text { body weight } \\
\text { in } 500 \mathrm{ml} \text { in at least } 60 \mathrm{~min} \text {. } \\
\text { Maximum dose: } 20 \mathrm{mg} / \mathrm{kg} \text { body } \\
\text { weight per day }\end{array}$ \\
\hline
\end{tabular}

(median; 25\%ile, 75\%ile: 0.2, 2.3) in the overall population, $1.4 \mathrm{~g} / \mathrm{dl}(0.3,2.3)$ in patients censored for transfusions during the study, $1.4 \mathrm{~g} / \mathrm{dl}(0.2$, 2.3 in patients who received FCM only, and 1.6 $\mathrm{g} / \mathrm{dl}(0.7,2.4)$ in patients who received FCM plus ESA. The transfusion rate between week 5 and end of observation amounted to $7 \%$ and $11 \%$ of patients treated with FCM and FCM + ESA, respectively.

\section{Safety of intravenous iron}

There are many oral iron formulations, but in Europe only six different preparations are available for intravenous use (Table 3). Most randomized studies (Tables 1 and 2) made use of iron natrium-gluconate-sucrose complex (in Europe: Ferrlecit ${ }^{\circledR}$, Sanofi-Aventis) as an adjunct to ESAs. All but one of these studies showed similar rates of adverse events (AEs) in patients receiving ESAs alone, ESAs plus oral iron or ESAs plus intravenous iron. One study [Steensma et al. 2011] revealed a substantially higher rate of SAEs in the intravenous iron arm (darbepoetin plus ferric natrium-gluconate-sucrose complex). It was conjectured that these may be due to the three single doses of ferric-gluconate given concomitantly with ESAs, instead of two doses as per the drug label [Aapro et al. 2011]. However, sometimes life-threatening anaphylactic reactions 
Table 4. Practice guidelines recommendations of iron management.

\begin{tabular}{|c|c|c|c|c|}
\hline & $\begin{array}{l}\text { Canadian guidelines } \\
\text { [Mikhael et al. 2007] }\end{array}$ & $\begin{array}{l}\text { EORTC [Bokemeyer } \\
\text { et al. 2007; Aapro and } \\
\text { Link, 2008] }\end{array}$ & $\begin{array}{l}\text { ASH/ASCO [Rizzo et } \\
\text { al. 2010] }\end{array}$ & NCCN [NCCN, 2012] \\
\hline Iron monitoring & $\begin{array}{l}\text { Baseline and periodic } \\
\text { monitoring }\end{array}$ & Baseline (exclude ID) & $\begin{array}{l}\text { Baseline and } \\
\text { periodic monitoring }\end{array}$ & $\begin{array}{l}\mathrm{Hb}<11 \mathrm{~g} / \mathrm{dl} \text { or }>2 \mathrm{~g} / \mathrm{dl} \\
\text { below baseline. } \\
\text { Patients considered for } \\
\text { ESA therapy }\end{array}$ \\
\hline Iron parameter & Ferritin, TSAT & Not defined & TSAT or ferritin & $\begin{array}{l}\text { Reticulocytes, MCV, } \\
\text { ferritin, TSAT }\end{array}$ \\
\hline Definition of ID & $\begin{array}{l}\text { SF }<100 \mathrm{ng} / \mathrm{mL}, \text { TSAT } \\
<15 \%\end{array}$ & Not defined & Not defined & $\begin{array}{l}\text { AID: SF }<30 \mathrm{ng} / \mathrm{mL}, \text { TSAT } \\
<15 \% \\
\text { FID: SF } \leq 800 \mathrm{ng} / \mathrm{mL}, \text { TSAT } \\
<20 \%\end{array}$ \\
\hline Iron supplement & $\begin{array}{l}\text { ID: iron iv first + ESA } \\
\text { (SF }<1000 \mathrm{ng} / \mathrm{mL} \text {, } \\
\text { TSAT }<35 \% \text { ) }\end{array}$ & $\begin{array}{l}\text { ID correction } \\
\text { AID and FID: iron iv }\end{array}$ & $\begin{array}{l}\text { ID correction iron iv } \\
\text { to be considered to } \\
\text { reduce ESA need, } \\
\text { but not as standard } \\
\text { of care }\end{array}$ & $\begin{array}{l}\text { AID: iron iv or oral } \\
\text { FID: iron iv as adjunct to } \\
\text { ESA }\end{array}$ \\
\hline $\begin{array}{l}\text { Iron iv dosing } \\
\text { regimen }\end{array}$ & $\begin{array}{l}\text { IS: } 100 \mathrm{mg} \mathrm{QW}, 200 \mathrm{mg} \\
\text { Q2-3W } \\
\text { SFG: } 125 \mathrm{mg} \mathrm{QW} \\
\text { LWID: } 100 \mathrm{mg} \text { QW } \\
\text { or TDI }\end{array}$ & $\begin{array}{l}\text { No dosing } \\
\text { recommendation }\end{array}$ & $\begin{array}{l}\text { No dosing } \\
\text { recommendation }\end{array}$ & $\begin{array}{l}\text { IS: } 200 \mathrm{mg} \text { Q2-3W } \\
\text { SFG: } 8 \times 125 \mathrm{mg} \text { QW or } 5 x \\
200 \mathrm{mg} \text { (3-4h) Q3W } \\
\text { Max } 1000 \mathrm{mg} \text { total dose } \\
\text { LWID: } 100 \mathrm{mg}\end{array}$ \\
\hline
\end{tabular}

as with older iron-dextran solutions have never been observed in cancer trials. In particular, the current high molecular weight sequestrants such as sucrose, isomaltosid and carboxymaltose have an excellent compatibility, not requiring a test dose at therapy initiation. In over 600 cancer patients treated with ferric carboxymaltose the rate of possibly or probably drug-related AEs, mainly nausea and diarrhea, were reported for $2.3 \%(n=14)$ of patients only. Three SAEs comprised one death after a possibly related respiratory insufficiency in a 74-year-old man with advanced, pulmonary-metastasized head and neck cancer and two unlikely related cases of tachycardia and dyspnea. However, in none of the trials published so far has there been any signal for initially discussed serious adverse drug reactions that might occur with intravenous iron in cancer patients such as increased risk of infection, tumor progression and problems associated with an iatrogenic hemochromatosis, e.g. cardiovascular or thromboembolic events [Marx, 2002; Bailie et al. 2005; Chertow et al. 2006; Auerbach et al. 2007].

\section{How should we manage anemia in cancer patients?}

When and by which diagnostic parameters should we assess iron metabolism?

In patients being treated for cancer the cause of anemia should be investigated if $\mathrm{Hb}$ rapidly decreases by $>2 \mathrm{~g} / \mathrm{dl}$ or falls below $11 \mathrm{~g} / \mathrm{dl}$ (Figure 1). Based on current practice guidelines (Table 4) at least SF and TSAT should be measured in addition to careful anamnesis. The assumption of FID should not be restricted to patients with $\mathrm{SF}<800$ $1000 \mathrm{ng} / \mathrm{ml}$ only, but additional parameters such as FI and hypochromic reticulocytes should be considered [Cazzola and Beguin, 1992; Pettersson et al. 1994; Suominen et al. 2000; Beguin, 2002; Lee et al. 2002; Thomas and Thomas, 2002].

\section{Which patients should be treated with iron?}

Patients with AID should always be treated with iron. In patients with FID iron should be considered as an adjunct to ESAs (Figure 1). There is some evidence that the response to ESAs might 
be enhanced even in patients not meeting the definition of AID and FID, e.g. patients with TSAT $>15 \%$ and SF $>10 \mathrm{ng} / \mathrm{ml}$ [Bastit et al. 2008] (Table 2). The noninterventional study with ferric carboxymaltose described an effective intravenous iron-only therapy even in patients with SF $>500 \mathrm{ng} / \mathrm{ml}$ [Steinmetz et al. 2011] (Table 2). Moreover, patients without any evidence of FID at baseline may also develop FID under ESA therapy as indicated by an increase of sTfR and FI [Steinmetz et al. 2010]. There is still an urgent need for prospective trials optimizing anemia treatment based on baseline assessment and monitoring of iron status and erythropoiesis.

\section{Should we treat patients with oral or intravenous iron?}

Three studies prospectively tested oral versus intravenous iron and none showed a significant benefit of oral iron [Auerbach et al. 2004; Henry et al. 2007; Steensma et al. 2011]. This might be due to hindered oral intake during chemotherapy and of course due to the common inflammation reaction giving rise to the release of hepcidin preventing enterocytes from iron discharge into the circulation. In patients with AID without inflammation oral iron will be effective. On the other hand, intravenous iron always entails a quicker response and lacks the risk of incomplete absorption and of side effects such as gastrointestinal discomfort and constipation.

What is the optimal intravenous dose of iron? In AID the need for iron might be calculated based on the formula of Ganzoni:

Total Fe dose $[\mathrm{mg}]=$ body weight $[\mathrm{kg}] \times$ (target$\mathrm{Hb}-$ actual $\mathrm{Hb}[\mathrm{g} / \mathrm{dl}]) \times 2.4+(500-1000 \mathrm{mg} \mathrm{Fe})$.

However, this approach was used in one trial only [Auerbach et al. 2004] which was based on a modified formula calculated a need of 1000$3000 \mathrm{mg}$ iron. The other studies combining ESAs with iron used a total dose between 750 and $2000 \mathrm{mg}$ at a fixed dose schedule (Table 1). Only in the first one [Auerbach et al. 2004] did a small group of patients $(n=41)$ receive the total dose as one infusion. The response was the same as in patients receiving the weekly schedule. One-week infusion intervals with single doses of 100-200 mg were used in five out of eight combined studies whereas in the remaining three studies there were 3-week intervals with single doses of 187 $400 \mathrm{mg}$, corresponding to weekly doses of 62.5 $133 \mathrm{mg}$. A weekly dose of $62.5 \mathrm{mg}$ was discussed to be too low as the study failed to show a significant benefit of intravenous iron [Aapro et al. 2011; Steensma et al. 2011]. In the observational study with ferric carboxymaltose patients received iron only at single doses of 500 or $1000 \mathrm{mg}$ and on average a total dose of $1000 \mathrm{mg}$ (median). Thus, the total dose might be $1000 \mathrm{mg}$ or more, but future dose optimization studies will be helpful.

\section{Which intravenous preparation should be used?}

Former reluctance in using intravenous iron was mostly driven by safety concerns, including life-threatening anaphylactic reactions. All of today's preparations show good or excellent tolerability (Table 3) and in particular macromolecular sequestrants such as carboxymaltose or isomaltosid allow for fast infusion of high total iron doses at low rates of side effects. Most experience in the cancer patient population is available for ferric carboxymaltose.

In summary, iron proved efficacious and effective for the treatment of cancer-associated anemia. Most studies confirmed an increased efficacy of the combination of ESAs with intravenous iron, but iron alone may be a useful option too. However, there is still an urgent need for trials investigating diagnostic approaches for the optimal tailoring of iron and/or ESA therapy in cancer patients with anemia.

\section{Acknowledgements}

Thanks are due to Uwe Totzke for reviewing and revising the draft version of the manuscript.

\section{Funding}

This research received no specific grant from any funding agency in the public, commercial, or notfor-profit sectors.

\section{Conflict of interest statement}

Dr. Steinmetz was engaged in clinical studies for Amgen, Roche, Ortho Biotec - Janssen Cilag, Vifor, as a consultant in ad-boards for Amgen, Roche, Ortho Biotec - Janssen Cilag, Vifor, Medice/Pharmacosmos, Holbek, and received grants for clinical studies for Amgen, Roche, Vifor. 


\section{References}

Aapro, M., Beguin, Y., Birgegard, G., Gascon, P., Hedenus, M. and Osterborg, A. (2011) Too-low iron doses and too many dropouts in negative iron trial? $\mathcal{F}$ Clin Oncol 29: e525-e526; author reply e527-e528.

Aapro, M.S. and Link, H. (2008) September 2007 update on EORTC guidelines and anemia management with erythropoiesis-stimulating agents. Oncologist 13(Suppl. 3): 33-36.

Auerbach, M., Ballard, H. and Glaspy, J. (2007) Clinical update: intravenous iron for anaemia. Lancet 369: 1502-1504.

Auerbach, M., Ballard, H., Trout, J.R., McIlwain, M., Ackerman, A., Bahrain, H. et al. (2004) Intravenous iron optimizes the response to recombinant human erythropoietin in cancer patients with chemotherapyrelated anemia: a multicenter, open-label, randomized trial. f Clin Oncol 22: 1301-1307.

Auerbach, M., Silberstein, P.T., Webb, R.T., Averyanova, S., Ciuleanu, T.E., Shao, J. et al. (2010) Darbepoetin alfa 300 or 500 mug once every 3 weeks with or without intravenous iron in patients with chemotherapy-induced anemia. Am $\mathcal{F}$ Hematol 85: 655-663.

Bailie, G.R., Clark, J.A., Lane, C.E. and Lane, P.L. (2005) Hypersensitivity reactions and deaths associated with intravenous iron preparations. Nephrol Dial Transplant 20: 1443-1449.

Barrett-Lee, P., Bokemeyer, C., Gascon, P., Nortier, J.W., Schneider, M., Schrijvers, D. et al. (2005) Management of cancer-related anemia in patients with breast or gynecologic cancer: new insights based on results from the European Cancer Anemia Survey. Oncologist 10: 743-757.

Bastit, L., Vandebroek, A., Altintas, S., Gaede, B., Pinter, T., Suto, T.S. et al. (2008) Randomized, multicenter, controlled trial comparing the efficacy and safety of darbepoetin alpha administered every 3 weeks with or without intravenous iron in patients with chemotherapy-induced anemia. $\mathcal{F}$ Clin Oncol 26: 1611-1618.

Beguin, Y. (2002) Prediction of response and other improvements on the limitations of recombinant human erythropoietin therapy in anemic cancer patients. Haematologica 87: 1209-1221.

Birgegard, G., Gascon, P. and Ludwig, H. (2006) Evaluation of anaemia in patients with multiple myeloma and lymphoma: findings of the European CANCER ANAEMIA SURVEY. Eur F Haematol 77: 378-386.

Bohlius, J., Schmidlin, K., Brillant, C., Schwarzer, G., Trelle, S., Seidenfeld, J. et al. (2009) Recombinant human erythropoiesis-stimulating agents and mortality in patients with cancer: a meta-analysis of randomised trials. Lancet 373: 1532-1542.

Bokemeyer, C., Aapro, M.S., Courdi, A., Foubert, J., Link, H., Osterborg, A. et al. (2007) EORTC guidelines for the use of erythropoietic proteins in anaemic patients with cancer: 2006 update. Eur $\mathcal{F}$ Cancer 43: 258-270.

Brownlie, T.t., Utermohlen, V., Hinton, P.S. and Haas, J.D. (2004) Tissue iron deficiency without anemia impairs adaptation in endurance capacity after aerobic training in previously untrained women. Am F Clin Nutr 79: 437-443.

Brugnara, C. (2000) Reticulocyte cellular indices: a new approach in the diagnosis of anemias and monitoring of erythropoietic function. Crit Rev Clin Lab Sci 37: 93-130.

Cash, J.M. and Sears, D.A. (1989) The anemia of chronic disease: spectrum of associated diseases in a series of unselected hospitalized patients. $\mathrm{Am} \mathcal{F} \mathrm{Med}$ 87: 638-644.

Cazzola, M. and Beguin, Y. (1992) New tools for clinical evaluation of erythron function in man. Br F Haematol 80: 278-284.

Chertow, G.M., Mason, P.D., Vaage-Nilsen, O. and Ahlmen, J. (2006) Update on adverse drug events associated with parenteral iron. Nephrol Dial Transplant 21: 378-382.

Dangsuwan, P. and Manchana, T. (2010) Blood transfusion reduction with intravenous iron in gynecologic cancer patients receiving chemotherapy. Gynecol Oncol 116: 522-525.

de Benoist, B., McLean, E., Egli, I. and Cogswell, M. (2008) Worldwide Prevalence of Anaemia 19932005: WHO Global Database on Anaemia. Geneva, Switzerland: World Health Organization.

Dubray, B., Mosseri, V., Brunin, F., Jaulerry, C., Poncet, P., Rodriguez, J. et al. (1996) Anemia is associated with lower local-regional control and survival after radiation therapy for head and neck cancer: a prospective study. Radiology 201: 553-558.

Fein, D.A., Lee, W.R., Hanlon, A.L., Ridge, J.A., Langer, C.J., Curran, W.J., Jr et al. (1995) Pretreatment hemoglobin level influences local control and survival of T1-T2 squamous cell carcinomas of the glottic larynx. F Clin Oncol 13: 2077-2083.

Fishbane, S., Frei, G.L. and Maesaka, J. (1995) Reduction in recombinant human erythropoietin doses by the use of chronic intravenous iron supplementation. Am F Kidney Dis 26: 41-46.

Glaser, C.M., Millesi, W., Kornek, G.V., Lang, S., Schull, B., Watzinger, F. et al. (2001) Impact of hemoglobin level and use of recombinant erythropoietin on efficacy of preoperative 
chemoradiation therapy for squamous cell carcinoma of the oral cavity and oropharynx. Int $\mathcal{F}$ Radiat Oncol Biol Phys 50: 705-715.

Glaspy, J., Bukowski, R., Steinberg, D., Taylor, C., Tchekmedyian, S. and Vadhan-Raj, S. (1997) Impact of therapy with epoetin alfa on clinical outcomes in patients with nonmyeloid malignancies during cancer chemotherapy in community oncology practice. Procrit Study Group. F Clin Oncol 15: 1218-1234.

Glaspy, J., Crawford, J., Vansteenkiste, J., Henry, D., Rao, S., Bowers, P. et al. (2010) Erythropoiesisstimulating agents in oncology: a study-level metaanalysis of survival and other safety outcomes. Br f Cancer 102: 301-315.

Goodnough, L.T., Nemeth, E. and Ganz, T. (2010) Detection, evaluation, and management of ironrestricted erythropoiesis. Blood 116: 4754-4761.

Grotto, H.Z. (2008) Anaemia of cancer: an overview of mechanisms involved in its pathogenesis. Med Oncol 25: $12-21$.

Hedenus, M., Birgegard, G., Nasman, P., Ahlberg, L., Karlsson, T., Lauri, B. et al. (2007) Addition of intravenous iron to epoetin beta increases hemoglobin response and decreases epoetin dose requirement in anemic patients with lymphoproliferative malignancies: a randomized multicenter study. Leukemia 21: 627-632.

Henry, D.H., Dahl, N.V., Auerbach, M., Tchekmedyian, S. and Laufman, L.R. (2007) Intravenous ferric gluconate significantly improves response to epoetin alfa versus oral iron or no iron in anemic patients with cancer receiving chemotherapy. Oncologist 12: 231-242.

Kim, Y.T., Kim, S.W., Yoon, B.S., Cho, H.J., Nahm, E.J., Kim, S.H. et al. (2007) Effect of intravenously administered iron sucrose on the prevention of anemia in the cervical cancer patients treated with concurrent chemoradiotherapy. Gynecol Oncol 105: 199-204.

Krause, A., Neitz, S., Magert, H.J., Schulz, A., Forssmann, W.G., Schulz-Knappe, P. et al. (2000) LEAP-1, a novel highly disulfide-bonded human peptide, exhibits antimicrobial activity. FEBS Lett 480: 147-150.

Lee, E.J., Oh, E.J., Park, Y.J., Lee, H.K. and Kim, B.K. (2002) Soluble transferrin receptor (sTfR), ferritin, and sTfR/log ferritin index in anemic patients with nonhematologic malignancy and chronic inflammation. Clin Chem 48: 1118-1121.

Littlewood, T.J., Bajetta, E., Nortier, J.W., Vercammen, E. and Rapoport, B. (2001) Effects of epoetin alfa on hematologic parameters and quality of life in cancer patients receiving nonplatinum chemotherapy: results of a randomized, double-blind, placebo-controlled trial. f Clin Oncol 19: 2865-2874.
Ludwig, H., Müldür, E., Endler, G., Hübl, W., Moneuse, P. and Klement, B. (2011) High prevalence of iron deficiency across different tumors correlates with anemia, increases during cancer treatment and is associated with poor performance status. Haematologica 96: Abstract 982.

Ludwig, H., Van Belle, S., Barrett-Lee, P., Birgegard, G., Bokemeyer, C., Gascon, P. et al. (2004) The European Cancer Anaemia Survey (ECAS): a large, multinational, prospective survey defining the prevalence, incidence, and treatment of anaemia in cancer patients. Eur F Cancer 40: 2293-2306.

Macdougall, I.C., Tucker, B., Thompson, J., Tomson, C.R., Baker, L.R. and Raine, A.E. (1996) A randomized controlled study of iron supplementation in patients treated with erythropoietin. Kidney Int 50: 1694-1699.

Marx, J.J. (2002) Iron and infection: competition between host and microbes for a precious element. Best Pract Res Clin Haematol 15: 411-426.

Mikhael, J., Melosky, B., Cripps, C., Rayson, D. and Kouroukis, C.T. (2007) Canadian supportive care recommendations for the management of anemia in patients with cancer. Curr Oncol 14: 209-217.

Mitchell, D. (2010) A European Patient Record Study on Diagnosis and Treatment of Chemotherapy-induced Anaemia. Milan, Italy: ESMO.

NCCN (2012) Practice Guidelines in Oncology; Cancer and Chemotherapy-Induced Anemia. Available at: http://www.nccn.org/professionals/ physician_gls/pdf/anemia.pdf.

Park, C.H., Valore, E.V., Waring, A.J. and Ganz, T. (2001) Hepcidin, a urinary antimicrobial peptide synthesized in the liver. $\mathcal{F}$ Biol Chem 276: $7806-7810$.

Pedrazzoli, P., Farris, A., Del Prete, S., Del Gaizo, F., Ferrari, D., Bianchessi, C. et al. (2008) Randomized trial of intravenous iron supplementation in patients with chemotherapy-related anemia without iron deficiency treated with darbepoetin alpha. $\mathcal{F}$ Clin Oncol 26: 1619-1625.

Pettersson, T., Kivivuori, S.M. and Siimes, M.A. (1994) Is serum transferrin receptor useful for detecting iron-deficiency in anaemic patients with chronic inflammatory diseases? Br F Rheumatol 33: 740-744.

Punnonen, K., Irjala, K. and Rajamaki, A. (1997) Serum transferrin receptor and its ratio to serum ferritin in the diagnosis of iron deficiency. Blood 89: 1052-1057.

Rizzo, J.D., Brouwers, M., Hurley, P., Seidenfeld, J., Arcasoy, M.O., Spivak, J.L. et al. (2010a) American Society of Clinical Oncology/American Society of Hematology clinical practice guideline update on the 
use of epoetin and darbepoetin in adult patients with cancer. F Clin Oncol 28: 4996-5010.

Rizzo, J.D., Brouwers, M., Hurley, P., Seidenfeld, J., Arcasoy, M.O., Spivak, J.L. et al. (2010b) American Society of Hematology/American Society of Clinical Oncology clinical practice guideline update on the use of epoetin and darbepoetin in adult patients with cancer. Blood 116: 4045-4059.

Rizzo, J.D., Lichtin, A.E., Woolf, S.H., Seidenfeld, J., Bennett, C.L., Cella, D. et al. (2002) Use of epoetin in patients with cancer: evidence-based clinical practice guidelines of the American Society of Clinical Oncology and the American Society of Hematology. Blood 100: 2303-2320.

Sepandj, F., Jindal, K., West, M. and Hirsch, D. (1996) Economic appraisal of maintenance parenteral iron administration in treatment of anaemia in chronic haemodialysis patients. Nephrol Dial Transplant 11: 319-322.

Spahn, D.R., Moch, H., Hofmann, A. and Isbister, J.P. (2008) Patient blood management: the pragmatic solution for the problems with blood transfusions. Anesthesiology 109: 951-953.

Steensma, D.P. (2011) Art of oncology: new voices wanted. f Clin Oncol 29: 3343-3344.

Steensma, D.P., Sloan, J.A., Dakhil, S.R., Dalton, R., Kahanic, S.P., Prager, D.J. et al. (2011) Phase III, randomized study of the effects of parenteral iron, oral iron, or no iron supplementation on the erythropoietic response to darbepoetin alfa for patients with chemotherapy-associated anemia. F Clin Oncol 29: 97-105.

Steinmetz, H.T., Tsamaloukas, A., Schmitz, S., Wiegand, J., Rohrberg, R., Eggert, J. et al. (2010) A new concept for the differential diagnosis and therapy of anaemia in cancer patients. Support Care Cancer 19: 261-269.

Steinmetz, T., Hellmich, M., Neise, M., Aldaud, A., Lerchenmuller, C., Tsamaloukas, A. et al. (2007) Prediction of the responsiveness to treatment with erythropoiesis-stimulating factors: a prospective clinical study in patients with solid tumors. Oncologist 12: $748-755$.
Steinmetz, T., Totzke, U., Schweigert, M., Mittermuller, J., Nawka, S., Tesch, H. et al. (2011) A prospective observational study of anaemia management in cancer patients - results from the German Cancer Anaemia Registry. Eur $\mathcal{F}$ Cancer Care (Engl) 20: 493-502.

Steinmetz, T., Totzke, U., Soling, U., Groschek, M., Mittermuller, J., Schweigert, M. et al. (2008) Hemoglobin levels that trigger erythropoiesis-stimulating agent treatment decisions for cancer-associated anemia-examination of practice in Germany. Curr Med Res Opin 24: 2751-2756.

Steinmetz, T., Tschechne, B., Virgin, G., Klement, B., Franzem, M., Wamhoff, J. et al. (2011) Ferric Carboxymaltose for the Correction of Cancer- and Chemotherapy-associated Anemia in Clinical Practice. London: EHA.

Suominen, P., Mottonen, T., Rajamaki, A. and Irjala, K. (2000) Single values of serum transferrin receptor and transferrin receptor ferritin index can be used to detect true and functional iron deficiency in rheumatoid arthritis patients with anemia. Arthritis Rheum 43: 1016-1020.

Thomas, C., Kobold, U., Balan, S., Roeddiger, R. and Thomas, L. (2011) Serum hepcidin-25 may replace the ferritin index in the Thomas plot in assessing iron status in anemic patients. Int $\mathcal{F ~} \mathrm{Lab}$ Hematol 33: 187-193.

Thomas, C. and Thomas, L. (2002) Biochemical markers and hematologic indices in the diagnosis of functional iron deficiency. Clin Chem 48: 1066-1076.

Verdon, F., Burnand, B., Stubi, C.L., Bonard, C., Graff, M., Michaud, A. et al. (2003) Iron supplementation for unexplained fatigue in nonanaemic women: double blind randomised placebo controlled trial. BMF 326: 1124.

Waters, J.S., O'Brien, M.E. and Ashley, S. (2002) Management of anemia in patients receiving chemotherapy. f Clin Oncol 20: 601-603.

Weiss, G. and Goodnough, L.T. (2005) Anemia of chronic disease. N Engl f Med 352: 1011-1023.
Visit SAGE journals online http://tah.sagepub.com

@SAGE journals 
